Adeolu Alex Adedapo*, Ehizogie Ruth Osaretin, Olufunke Olubunmi Falayi, Ademola Adetokunbo Oyagbemi, Blessing Seun Ogunpolu, Temidayo Olutayo Omobowale, Oluwafemi Omoniyi Oguntibeju and Momoh Audu Yakubu

\title{
Ramipril blunts glycerol-induced acute renal failure in rats through its antiapoptosis, anti- inflammatory, antioxidant, and renin-inhibiting properties
}

https://doi.org/10.1515/jbcpp-2020-0032

Received April 15, 2020; accepted July 24, 2020;

published online November 6, 2020

\section{Abstract}

Objectives: Acute kidney injury (AKI) is a malady with a sudden onset resulting in buildup of waste matters in the body, but a specific cure hasn't been found as a lasting solution to AKI. In this study, ramipril was evaluated for its potential therapy in glycerol-induced AKI in rats.

Methods: Twenty animals were divided into four groups of five animals each. Group I was the control while group II was given glycerol on day 8 only, groups III and IV were administered with pioglitazone (reference drug) and ramipril for seven days respectively and on day 8 received glycerol. On the ninth day, blood and tissue samples were taken to assay for serum indicators of oxidative damage, enzymatic and nonenzymatic antioxidants, and creatinine and blood urea nitrogen. Animals were sacrificed thereafter; kidney was harvested for histological and immunohistochemical

*Corresponding author: Adeolu Alex Adedapo, Department of Veterinary Pharmacology and Toxicology, University of Ibadan, Ibadan, Nigeria, Phone: +2348162746222,

E-mail: adedapo2a@gmail.com

Ehizogie Ruth Osaretin and Olufunke Olubunmi Falayi, Department of Veterinary Pharmacology and Toxicology, University of Ibadan, Ibadan, Nigeria

Ademola Adetokunbo Oyagbemi, Department of Veterinary Physiology and Biochemistry, University of Ibadan, Ibadan, Nigeria Blessing Seun Ogunpolu and Temidayo Olutayo Omobowale, Department of Veterinary Medicine, University of Ibadan, Ibadan, Nigeria

Oluwafemi Omoniyi Oguntibeju, Department of Biomedical Sciences, Cape Peninsula University of Technology, Bellsville, South Africa

Momoh Audu Yakubu, Department of Environmental and Interdisciplinary Sciences, College of Science, Engineering and Technology, Texas Southern University, Houston, TX, USA analysis. Expressions of caspase 3, renin receptor, NK-KB, and KIM-1 were carried out.

Results: Ramipril significantly inhibited indicators of oxidative damage while also significantly increasing levels of enzymatic and nonenzymatic antioxidant markers. These drugs also significantly lowered the levels of creatinine and blood urea nitrogen. Histology also indicated that while there were massive infiltration of leucocytes and congestion of the kidney in toxicant group, the ramipril-treated group showed a milder condition. In immunohistochemistry, the two drugs significantly inhibited the expressions of the four proteins, which were highly expressed in the toxicant group.

Conclusions: The study showed that ramipril and pioglitazone have nephroprotective effect and thus have the ability to blunt AKI through their anti-inflammatory, antiapoptosis, antirenin, and antioxidant properties.

Keywords: acute kidney injury; oxidative stress; ramipril.

\section{Introduction}

Acute kidney injury (AKI) formerly known as acute renal failure (ARF) is an abrupt incidence of kidney damage that occurs within a few hours or a few days. AKI results in an accumulation of waste products in the blood, thus making it hard for the kidney to maintain fluid homeostasis in the body. It affects other organs such as the heart, brain, and lungs [1]. About 33-50\% potential complications of AKI occurred in patients affected by both traumatic and nontraumatic rhabdomyolysis. This is the major cause of their mortality [2-4]. The pathogenesis of AKI has to do with the upturn of myoglobinemia, leading to constriction of the arteries and the subsequent accumulation of myoglobin and uric acid within the lumens of renal tubules, resulting in tubular necrosis and obstruction. The overall effect is a decrease in the glomerular filtration rate (GFR) and the formation of AKI [2-5]. 
The damage of renal tubules is a pathological feature of AKI. Presently, animal models of glycerol-induced AKI are generally used [6]. Upon administration of glycerol injection into the muscle, myoglobin and some other muscle contents are released into the blood stream, eventually causing AKI. Research has shown that the pathogenesis of glycerol-induced AKI involves myoglobin toxicity [7-9], reactive oxygen species (ROS) [10-12], inflammation [13], apoptosis [14, 15], and redox-active iron [12]. Despite the complexity of the pathogenesis of AKI, recuperation can be promoted via timely prophylactic and/or early therapeutic interventions $[10,15,16]$. It has been suggested that renal vasoconstriction, tubular obstruction, and direct myoglobin-induced cytotoxicity are the main mechanisms involved in AKI [3, 17]. Oxidative damage has also been incriminated in the pathogenesis of this condition [17-19].

Pioglitazone, which works on reversing almost all mechanisms involved in the pathogenesis, was suggested as a preventive option in some studies [20, 21]. Some studies have also indicated its renoprotective effects in other nephropathy models [22-24]. Pioglitazone is an oral antidiabetic agent and is classified as a peroxisome proliferator-activated receptor-gamma (PPAR- $y$ ) agonist (a member of thiazolidinediones), which binds to a specific site on the DNA helix. It participates in the control of transcription of numerous target genes and thus participates in the regulation of several vital processes such as adipocyte differentiation and also lipid and carbohydrate metabolism [20, 21]. In this study, pioglitazone is used as a reference drug and the renoprotective effect of ramipril was compared with that of pioglitazone.

Ramipril, an angiotensin-converting enzyme (ACE) inhibitor, is metabolized to its active form, ramiprilat, in the liver and to a little extent in the kidneys [25]. Ramipril at is an effective and competitive inhibitor of ACE. This enzyme is responsible for the conversion of angiotensin I (ATI) to angiotensin II (ATII) [26]. ATII, which is an essential part of RAAS, can be used to control blood pressure [27]. The drug, ramipril, may find its usefulness in the treatment of hypertension, congestive heart failure, and nephropathy. It could also be used to reduce the rate of death, stroke, and myocardial infarction in individuals suffering from cardiovascular problems [28]. Ramipril (Altace), an ACE inhibitor, has been used to reduce the relative risk of stroke. It is used other than its original function and this is termed drug repurposing.

It should be noted that ARF management is mainly supportive, but renal replacement therapy (RRT) may be the best course [29]. Regardless of RRT, mortality in patients with AKI is still high largely due to the severity of the disease or the adverse effects of RRT [30]; hence use of drug of ACE inhibitor class may be of help in this study.

\section{Materials and methods}

\section{Animals}

Albino rats ranging in weight between 130 and $220 \mathrm{~g}$ were kept at the experimental animal holding of the Faculty of Veterinary Medicine, University of Ibadan where they were accommodated in rats' cages and fed with accepted rats' feed. They had access to clean water ad libitum. They were maintained at room temperature $\left(25^{\circ} \mathrm{C}\right)$. They were allowed to adapt to their new environment for 2 weeks prior to the commencement of induction and treatment. Rats were kept under constant conditions (temperature $25 \pm 3{ }^{\circ} \mathrm{C}$ and humidity 50\%) with $12 / 12 \mathrm{~h}$ light/ dark cycles. All experimental procedures were in conformity with the University of Ibadan Ethics Committee on Research in Animals with the institutional approval number as UI-ACUREC/17/0064. Animals were selected into four groups of five animals per group as follow:

Group A: Untreated control group: Animals were not induced but were given distilled water for a period of 8 days, and so they served as normal control group. Group B: Toxicant group: Animals were given distilled water for 7 days, but on the day 8, acute kidney injury was induced by administering glycerol at $4 \mathrm{~mL} / \mathrm{kg}$ at a $50 \%$ dilution rate (double dilution). Group C: Pioglitazone-treated group (reference drug): Animals were treated using pioglitazone at $25 \mathrm{mg} / \mathrm{kg}$ for a period of 7 days and were induced using glycerol at $4 \mathrm{~mL} / \mathrm{kg}$ on the eighth day. Group D: Ramipril-treated group: Animals were treated using ramipril at $1 \mathrm{mg} / \mathrm{kg}$ for 7 days and were induced using glycerol at $4 \mathrm{~mL} / \mathrm{kg}$ on the eighth day.

\section{Blood sample collection}

On the ninth day, blood samples were obtained through the retroorbital venous plexus into clean heparinized tubes, and the serum samples obtained were collected into plain bottles and were rapidly centrifuged at 4000 revolutions per minute (rpm) for fifteen (15) min. Biochemical parameters such as serum creatinine, serum urea, myeloperoxidase, total protein, and xanthine oxidase and nitric oxide were analyzed thereof. After blood sample collection, the animals were euthanized by cervical decapitation after which kidneys from all the animals were harvested and kept in the freezer for further biochemical assays.

\section{Renal homogenate preparation}

The harvested kidneys were quickly removed, weighed, and perfused immediately with normal saline and homogenized in cold potassium phosphate buffer (0.1 M, pH 7.4) at $10000 \mathrm{rpm}$ for $15 \mathrm{~min}$, the homogenate was cold centrifuged at $4{ }^{\circ} \mathrm{C}$ to obtain post mitochondrial fraction (PMF). It was the supernatant obtained that was used to assay for total protein, reduced glutathione (GSH) levels, glutathione peroxidase (GPx), glutathione transferase (GST), superoxide dismutase (SOD), total thiol, nonprotein thiol (NPT), advanced oxidative protein product (AOPP), hydrogen peroxide $\left(\mathrm{H}_{2} \mathrm{O}_{2}\right)$ generation, malondialdehyde (MDA) content, and protein carbonyl (PC). 


\section{Biochemical assays}

Renal markers of oxidative stress: The method of Wolff [31] was used to determine the hydrogen peroxide generation with the reaction mixture subsequently incubated at room temperature for $30 \mathrm{~min}$. While the mixtures were read at absorbance at $560 \mathrm{~nm}, \mathrm{H}_{2} \mathrm{O}_{2}$ generated was extrapolated from $\mathrm{H}_{2} \mathrm{O}_{2}$ standard curve. The MDA content was quantified according to the method of Varshney and Kale [32]. The absorbance was measured against a blank of distilled water at $532 \mathrm{~nm}$. Calculation of lipid peroxidation was with a molar extinction coefficient of $1.56 \times 10^{5} / \mathrm{M} / \mathrm{cm}$. Using the method of Reznick and Packer [33], PC contents in the renal tissues were measured with the absorbance of the sample measured at $370 \mathrm{~nm}$. Based on the molar extinction coefficient of DNPH $\left(2.210^{4} \mathrm{~cm}^{1} \mathrm{M}^{1}\right)$, the carbonyl content was calculated and expressed as nmoles/mg protein. The AOPP contents were as determined by Kayali et al. [34]. In this study, $0.4 \mathrm{~mL}$ of renal PMFs were treated with $0.8 \mathrm{~mL}$ phosphate buffer $(0.1 \mathrm{M}$; $\mathrm{pH} 7.4)$, and the absorbance of the reaction mixture was immediately recorded at $340 \mathrm{~nm}$ wavelength. Using the extinction coefficient of $261 \mathrm{~cm}^{-1} \mathrm{mM}^{-1}$, the content of AOPP for each sample was calculated and the results were expressed as $\mu$ moles/mg protein.

Renal antioxidant markers: The SOD assay, reduced GSH estimation, GPx activity, GST estimation were all carried out by the method of Oyagbemi et al. [35]. The protein thiol (PT), NPT contents and protein concentration were determined as described by Omobowale et al. [36].

Determination of serum markers of renal damage: While the method of Olaleye et al. [37] was used to measure the serum nitric oxide concentrations at $548 \mathrm{~nm}$, the determination of the serum myeloperoxidase (MPO) activity was carried out according to the method of Xia and Zweier [38].

Renal function tests: The determination of blood urea nitrogen (BUN) and creatinine in this study was carried out using Randox kits in line with manufacturer's instructions.

Histopathology: Kidneys from all four groups were fixed in $10 \%$ neutral buffered formalin and processed to paraffin wax. The kidneys were sectioned longitudinally in two halves and were kept in 10\% neutral formalin solution. The sections were stained with hematoxylin and eosin and were observed under a light microscope [39].

\section{Immunohistochemistry}

The expression of kidney injury molecule I (KIM-1), caspase 3, renin receptor, and nuclear factor kappa beta (NF- $\mathrm{kB}$ ) in the kidney, using immunohistochemistry, was as described by Oyagbemi et al. [40]. The kidney tissues obtained from buffered formalin perfused rats were paraffin embedded and then used for immunohistochemistry. Paraffin sections were melted at $60{ }^{\circ} \mathrm{C}$ in the oven, but the dewaxing of the samples in xylene was followed by passage through decreasing concentrations of ethanol (100-80\%). Peroxidase quenching in $3 \% \mathrm{H}_{2} \mathrm{O}_{2} /$ methanol was carried out with subsequent antigen retrieval performed by microwave heating in $0.01 \mathrm{M}$ citrate buffer ( $\mathrm{pH}$ 6.0) to boil. Detection of bound antibody was carried out using biotinylated (goat antirabbit, $2.0 \mu \mathrm{g} / \mathrm{mL}$ ) secondary antibody and, subsequently, streptavidin peroxidase (horseradish peroxidase-streptavidin) according to the manufacturer's protocol (HistoMark ${ }^{\circledR}, \mathrm{KPL}$, Gaithersburg, MD, USA). Diaminobenzidine (DAB, Amresco ${ }^{\circledR}$, USA) was used to enhance the reaction product for 6-10 $\mathrm{min}$ and counterstained with highdefinition hematoxylin (Enzo®, NY, USA) and was thereafter dehydrated in ethanol. Once the slides were covered with cover slips, they were sealed with resinous solution. The immunoreactive positive expression of Kim-1 and NF- $\mathrm{BB}$ antirabbit intensive regions were viewed starting from low magnification on each slice then at $400 \times$ magnifications.

\section{Data analysis}

All values were stated as mean \pm S.D. One-way analysis of variance (ANOVA) with Tukey's post-hoc test was carried out using Graph Pad Prism version 4.00.

\section{Results}

Results from this study show that ramipril and pioglitazone (reference drug) significantly increased the levels of renal nonenzymatic antioxidants i.e., NPT, PT, vitamin C, and reduced GSH. These results are also comparable to that of group A (Table 1).

Table 2 shows the effects of ramipril on renal enzymatic antioxidants. In this instance, SOD, GST, and GPx all experienced significant increase when compared to the

Table 1: Effects of ramipril and pioglitazone on renal nonenzymatic antioxidant markers in glycerol-induced acute kidney injury.

\begin{tabular}{lrrrr}
\hline Parameters & A & B & C & D \\
\hline NPT & $24.79 \pm 4.39$ & $18.44 \pm 2.76^{\mathrm{a}}$ & $21.57 \pm 4.14$ & $20.25 \pm 1.78^{\mathrm{a}}$ \\
PT & $14.4 \pm 3.2$ & $7.62 \pm 1.93^{\mathrm{a}}$ & $11.7 \pm 0.09^{\mathrm{b}}$ & $10.3 \pm 0.10^{\mathrm{a}, \mathrm{b}}$ \\
Vitamin C & $3.09 \pm 0.11$ & $2.13 \pm 0^{\mathrm{a}}$ & $2.91 \pm 0.12^{\mathrm{a}, \mathrm{b}}$ & $2.69 \pm 0.17^{\mathrm{a}, \mathrm{b}}$ \\
GSH & $40.99 \pm 4.42$ & $47.16 \pm 4.29$ & $42.89 \pm 4.21$ & $40.21 \pm 7.92$ \\
\hline
\end{tabular}

Values expressed as mean \pm S.D. Group A (normal control), Group B (glycerol at $4 \mathrm{~mL} / \mathrm{kg}$ ), Group C (pioglitazone at $25 \mathrm{mg} / \mathrm{kg}+\mathrm{glycerol} \mathrm{at} 4 \mathrm{~mL} / \mathrm{kg}$ ), and Group D (glycerol at $4 \mathrm{~mL} / \mathrm{kg}$ + ramipril at $1 \mathrm{mg} / \mathrm{kg}$ ) at $\alpha<0.05$. GSH (reduced glutathione; $\mu \mathrm{mol} / \mathrm{mg}$ protein), NPT (nonprotein thiol; $\mu \mathrm{mol} / \mathrm{mg}$

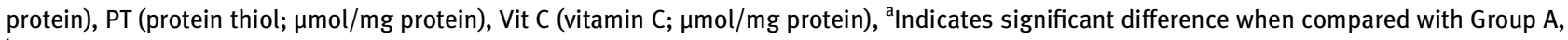
${ }^{\mathrm{b}}$ Indicates significant difference when compared with Group B. 
Table 2: Effects of ramipril and pioglitazone on renal enzymatic antioxidant markers.

\begin{tabular}{lrrrr}
\hline Groups & A & B & C & D \\
\hline SOD & $30.26 \pm 1.33$ & $25.88 \pm 2.21^{\mathrm{a}}$ & $26.73 \pm 1.18^{\mathrm{a}}$ & $27.42 \pm 2.15^{\mathrm{a}}$ \\
GST & $1.74 \pm 0.15$ & $0.61 \pm 0.25^{\mathrm{a}}$ & $1.03 \pm 0.28^{\mathrm{a}, \mathrm{b}}$ & $1.17 \pm 0.3^{\mathrm{a}, \mathrm{b}}$ \\
GPx & $137.75 \pm 23.59$ & $75.81 \pm 34.79^{\mathrm{a}}$ & $126.71 \pm 10.35^{\mathrm{a}}$ & $114.83 \pm 18.85^{\mathrm{a}, \mathrm{b}}$ \\
\hline
\end{tabular}

Values expressed as mean \pm S.D. Group A (normal control), Group B (glycerol $4 \mathrm{~mL} / \mathrm{kg}$ ), Group C (pioglitazone $25 \mathrm{mg} / \mathrm{kg}+\mathrm{glycerol} 4 \mathrm{~mL} / \mathrm{kg}$ ), and Group D (glycerol $4 \mathrm{~mL} / \mathrm{kg}$ + ramipril $1 \mathrm{mg} / \mathrm{kg}$ ) at $\alpha<0.05$. SOD (superoxide dismutase; $\mu \mathrm{mol} / \mathrm{mg}$ protein), GST (glutathione-S transferase; mmol

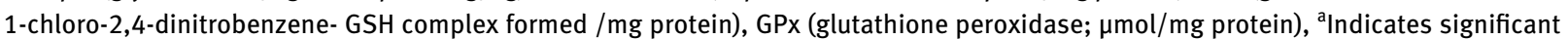

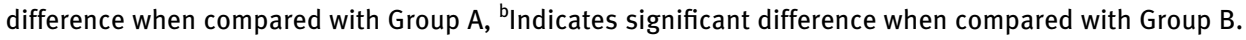

Table 3: Effects of ramipril and pioglitazone on renal nonenzymatic markers of oxidative stress.

\begin{tabular}{lrrrr}
\hline Groups & A & B & C & D \\
\hline $\mathrm{PC}$ & $3.35 \pm 0.80$ & $5.84 \pm 1.47^{\mathrm{a}}$ & $5.19 \pm 0.35^{\mathrm{a}}$ & $3.75 \pm 1.39^{\mathrm{a}, \mathrm{b}}$ \\
$\mathrm{H}_{2} \mathrm{O}_{2}$ & $26.33 \pm 1.92$ & $62.16 \pm 11.55^{\mathrm{a}}$ & $52.62 \pm 12.62^{\mathrm{a}}$ & $49.92 \pm 11.15^{\mathrm{a}, \mathrm{b}}$ \\
$\mathrm{MDA}$ & $0.26 \pm 0.01$ & $0.32 \pm 0.01^{\mathrm{a}}$ & $0.29 \pm 0.02^{\mathrm{b}}$ & $0.29 \pm 0.00^{\mathrm{b}}$ \\
\hline
\end{tabular}

Values expressed as mean \pm S.D. Group A (normal control), Group B (glycerol $4 \mathrm{~mL} / \mathrm{kg}$ ), Group C (pioglitazone $25 \mathrm{mg} / \mathrm{kg}+\mathrm{glycerol} 4 \mathrm{~mL} / \mathrm{kg}$ ), and Group D (glycerol $4 \mathrm{~mL} / \mathrm{kg}+$ ramipril $1 \mathrm{mg} / \mathrm{kg}$ ) at $\alpha<0.05$. PC (protein carbonyl; $\mu \mathrm{mol} / \mathrm{mg}$ protein), $\mathrm{H}_{2} \mathrm{O}_{2}$ (hydrogen peroxide; $\mu \mathrm{mol} / \mathrm{mg} \mathrm{protein),}$ MDA (malondialdehyde; $\mu \mathrm{mol} / \mathrm{mg}$ protein), ${ }^{\mathrm{a}}$ Indicates significant difference when compared with Group A, ${ }^{\mathrm{b}}$ Indicates significant difference when compared with Group B.

toxicant group. While the results of SOD for ramipril and pioglitazone were comparable to that of group A, for GST and GPx, the group A results showed a significant difference when compared to the results for the two drugs.

In Table 3, the effect of ramipril and pioglitazone on renal markers of oxidative stress i.e., PC, hydrogen peroxide, and MDA was that of significant decrease when compared to that of the toxicant.

The effect of pioglitazone and ramipril on serum markers of inflammation (myeloperoxidase and nitric oxide) levels is shown in Figure 1. While the two drugs caused significant decrease in the level of myeloperoxidase when compared to the toxicant group, reverse is the case for the nitric oxide where the tested agents caused significant increase in the level of this marker compared to that of the toxicant.

In Figure 2, the effect of pioglitazone and ramipril on serum urea and creatinine levels showed that there was a significant decrease in the levels of these biomarkers when compared to that of the toxicant group.

Figure 3 showed the effect of pioglitazone and ramipril on serum AOPP level where ramipril and pioglitazone caused a significant decrease in the level of this product.

In Figure 4, histology of the kidney (X400), stained with hematoxylin and eosin, was shown. While Group A (distilled water alone) shows normal morphology of the kidney tissue, Group B (glycerol) shows zones of congestion, infiltration of inflammatory cells, and degeneration of renal cells, Group C (pioglitazone) shows areas of congestion, and Group D (ramipril) also shows areas of congestion.

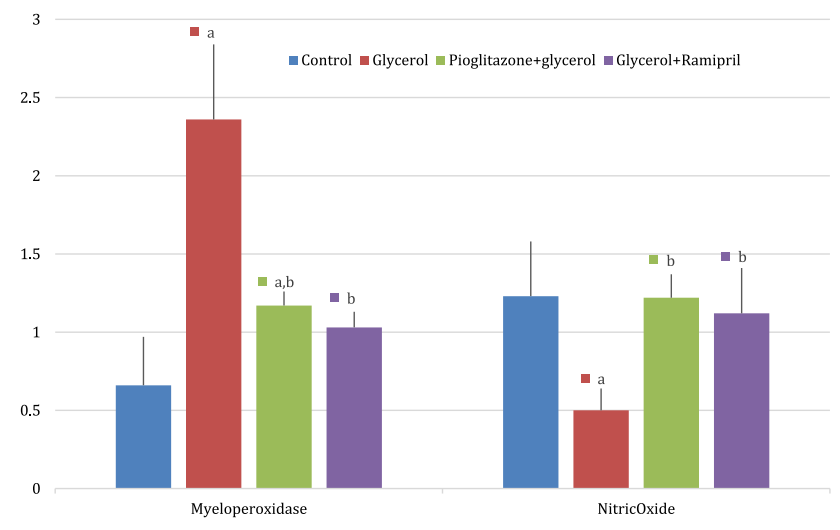

Figure 1: Effect of pioglitazone and ramipril on serum markers of inflammation (myeloperoxidase and nitric oxide) levels. Group A (normal control), Group B (glycerol at $4 \mathrm{~mL} / \mathrm{kg}$ ), Group C (pioglitazone at $25 \mathrm{mg} / \mathrm{kg}+$ glycerol at $4 \mathrm{~mL} / \mathrm{kg}$ ), and Group D (glycerol at $4 \mathrm{~mL} / \mathrm{kg}+$ ramipril at $1 \mathrm{mg} / \mathrm{kg}$ ). ${ }^{\mathrm{a}}$ Indicates significant difference when compared with Group A. 'Indicates significant difference when compared with Group B.

In Figure 5, the toxicant group (glycerol alone) caused significant expression of Caspase 3 while ramipril and pioglitazone caused significant inhibition of expression of this protein. The effect of these drugs on the protein expression is similar to that of the control.

Figure 6 showed that the toxicant group (glycerol alone) caused significant expression of renin receptor while ramipril and pioglitazone caused significant inhibition of expression of this protein. The effect of these drugs on the protein expression is similar to that of the control. 


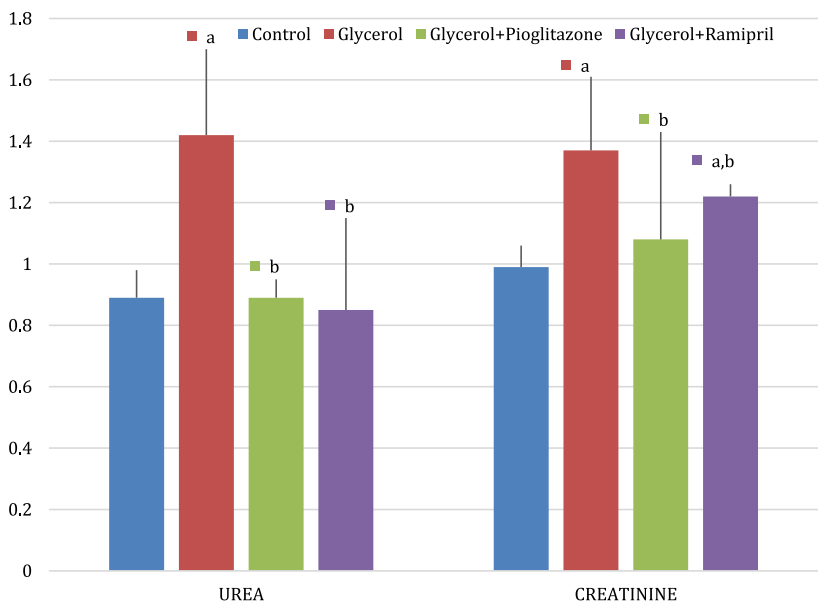

Figure 2: Effect of pioglitazone and ramipril on serum urea and creatinine levels. Group A (normal control), Group B (glycerol at $4 \mathrm{~mL} / \mathrm{kg}$ ), Group C (pioglitazone at $25 \mathrm{mg} / \mathrm{kg}$ + glycerol at $4 \mathrm{~mL} / \mathrm{kg}$ ), and Group D (glycerol at $4 \mathrm{~mL} / \mathrm{kg}$ + ramipril at $1 \mathrm{mg} / \mathrm{kg}$ ). ${ }^{a}$ Indicates significant difference when compared with Group A, ${ }^{\mathrm{b}}$ Indicates significant difference when compared with Group B.

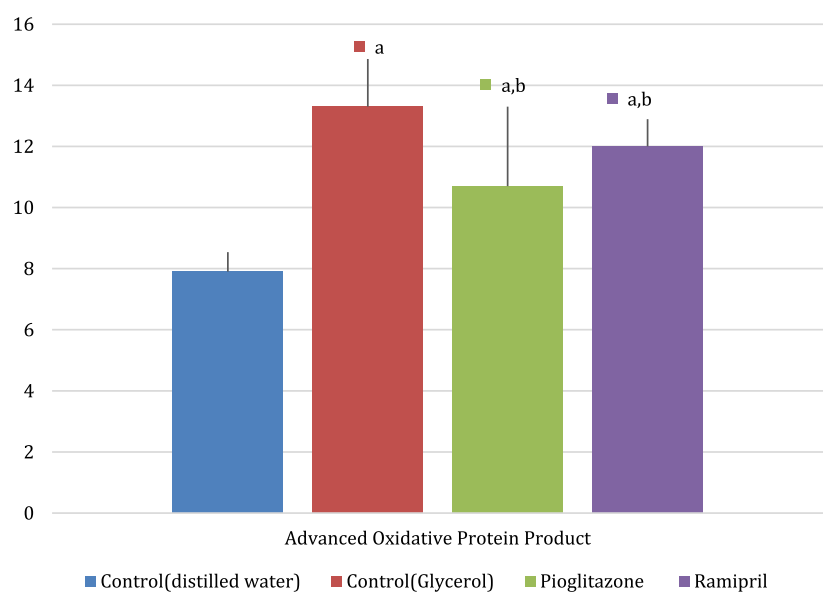

Figure 3: Effect of pioglitazone and ramipril on serum advanced oxidative protein product level. Group A (normal control), Group B (glycerol $4 \mathrm{~mL} / \mathrm{kg}$ ), Group C (pioglitazone $25 \mathrm{mg} / \mathrm{kg}$ + glycerol $4 \mathrm{~mL} / \mathrm{kg}$ ), and Group D (glycerol $4 \mathrm{~mL} / \mathrm{kg}$ + ramipril $1 \mathrm{mg} / \mathrm{kg}$ ). Indicates significant difference when compared with Group A, ${ }^{\mathrm{b}}$ Indicates significant difference when compared with Group B.

The toxicant group (glycerol alone) caused significant expression of KIM-1 while ramipril and pioglitazone caused significant inhibition of expression of this protein. The effect of these drugs on the protein expression is more pronounced even that of the control (Figure 7).

In Figure 8, the toxicant group (glycerol alone) caused significant expression of NF- $\mathrm{kB}$ while ramipril and pioglitazone caused significant inhibition of expression of this protein. The effect of these drugs on the protein expression is similar to that of the control.

\section{Discussion}

Glycerol-induced renal damage in laboratory animals closely mirrors rhabdomyolysis with the pathogenesis involving reactive oxygen metabolites and others. On the other hand, ischemia-reperfusion-induced ARF in humans mimics the hemodynamic-induced changes in renal function [41].

$\mathrm{PC}, \mathrm{H}_{2} \mathrm{O}_{2}$, and MDA levels were significantly elevated in the toxicant group only while pioglitazone and ramipril reduced their levels to almost as close as that of the control group as seen in Table 3. The free radical species generated by rhabdomyolysis in AKI promotes lipid peroxidation leading to production of MDA [42]. The elevation in MDA levels in the toxicant shows that glycerol could cause lipid peroxidation with subsequent damage of macromolecules.

PCs are used as representative indicators of protein oxidation and many diseases such as pancreatitis, Alzheimer's disease, etc., are linked with it [43]. Pathogenesis occurs by oxidation of glutamyl side chains; this leads to the generation of a peptide in which the N-terminal amino acid is blocked by an $\alpha$-ketoacyl derivative [44].

Hydrogen peroxide has been said to exert its effect by causing oxidation of thiol compound [45]. This is confirmed by the reduced thiol levels as reported in this study. Hydrogen peroxide is also changed to water and oxygen by GPx.

Increase in AOPP contents is connected with oxidative stress, inflammation, and acute renal damage [46]. The inhibition of oxidative stress by ramipril in this study indicates that this drug not only inhibits angiotensin-converting enzyme, but it also inhibits the production of free radicals and ROS.

AKI is typified by a sudden decline in renal function, demonstrated by a boost in serum creatinine levels [47]. A significant elevation was seen in the urea and creatinine levels of the toxicant only, while treatment with ramipril and pioglitazone decreased these levels to almost that of the control group. This result is comparable to that of Higgins et al. [48]. Urea and creatinine are traditional markers of renal damage, thus the elevation in urea and creatinine levels in this study confirmed glycerol-induced renal damage.

MPO is expressed mainly in neutrophils [49] and is an important enzyme in inflammatory processes, thus there is substantial proof that undue stimulation of oxidant generation of this enzyme can lead to host tissue damage [50]. Also, its proinflammatory effects have made selective inhibitors of iNOS an anti-inflammatory drug target [51]. 


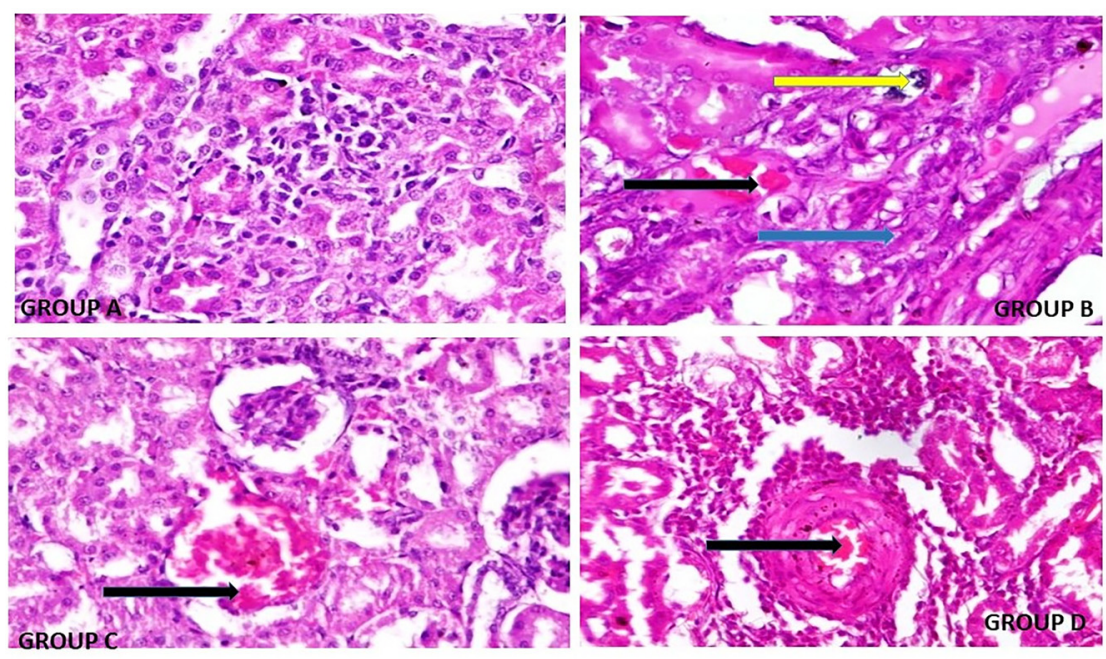

Black arrow indicates congestion, yellow arrow indicates clumped inflammatory cells and blue arrow indicates degeneration of renal cells

IMMUNOHISTOCHEMISTRY OF CASPASE 3
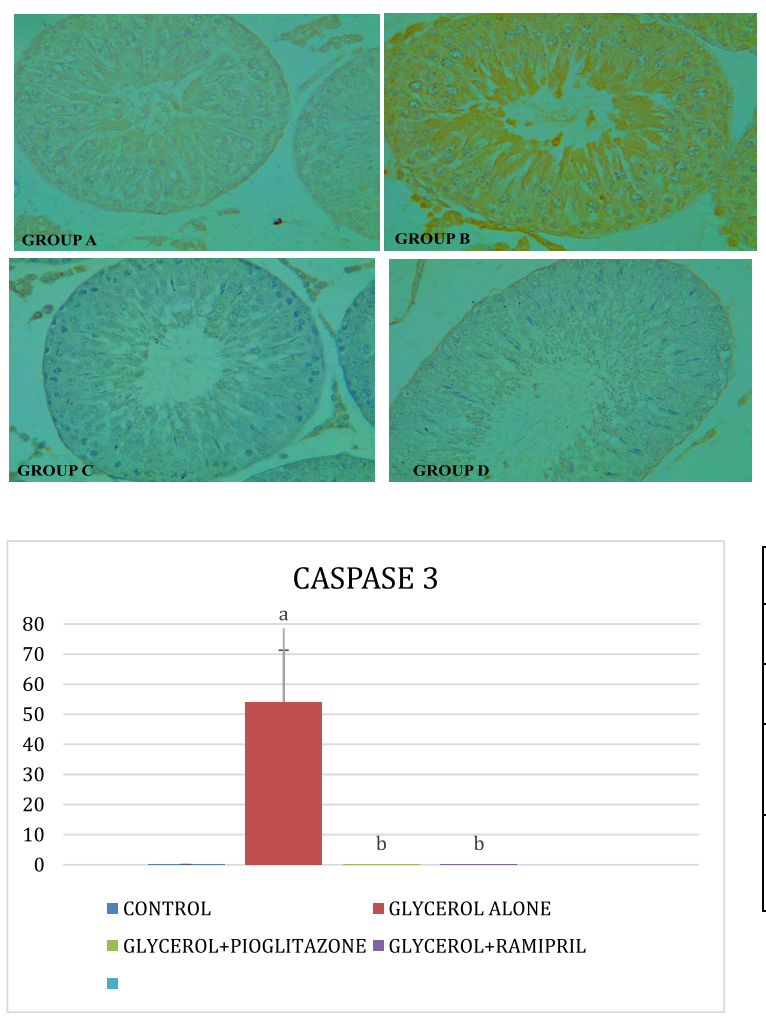

\begin{tabular}{|l|l|}
\hline GROUP & CASPASE-3 \\
\hline Control & $0.01 \pm 0.004$ \\
\hline Glycerol alone & $54 \pm 17.9^{\mathrm{a}}$ \\
\hline $\begin{array}{l}\text { Glycerol }+ \\
\text { Pioglitazone }\end{array}$ & $0.03 \pm 0.002^{\mathrm{b}}$ \\
\hline $\begin{array}{l}\text { Glycerol } \\
\text { Ramipril }+\end{array}$ & $\begin{array}{l}0.034 \pm 0.000 \\
01^{\mathrm{b}}\end{array}$ \\
\hline
\end{tabular}

In this study, AOPP, urea, creatinine, NO, and MPO all showed elevated levels in the toxicant group. However, treatment with ramipril and pioglitazone (reference drug) in the other groups reduced these levels to almost that of the control group indicating the anti-inflammatory and antioxidant effects of these drugs.

Thiol is an organosulfur compound that possesses antioxidant and radical scavenging properties [52] with a
Figure 4: Histology of the kidney (X400), stained with hematoxylin and eosin. Group A (distilled water alone) shows normal morphology of the kidney tissue. Group B (glycerol) shows zones of congestion, infiltration of inflammatory cells, and degeneration of renal cells, Group C (pioglitazone) shows areas of congestion, and Group D (ramipril) also shows areas of congestion.
Figure 5: The toxicant group (glycerol alone) caused significant expression of caspase 3 while ramipril and pioglitazone caused significant inhibition of expression of this protein. The effect of these drugs on the protein expression is similar to that of the control. significant role in defense against ROS [53]. In this study, there was a significant depletion in the levels of renal protein and NPT in the glycerol alone group; however, ramipril and pioglitazone elevated their levels to almost the same as that of the control groups. There was no significant difference in the NPT levels across the groups. The pioglitazone-treated groups had their PT levels elevated to almost the same level as the control. Thiol is an important 


\section{IMMUNOHISTOCHEMISTRY OF RENIN RECEPTOR}
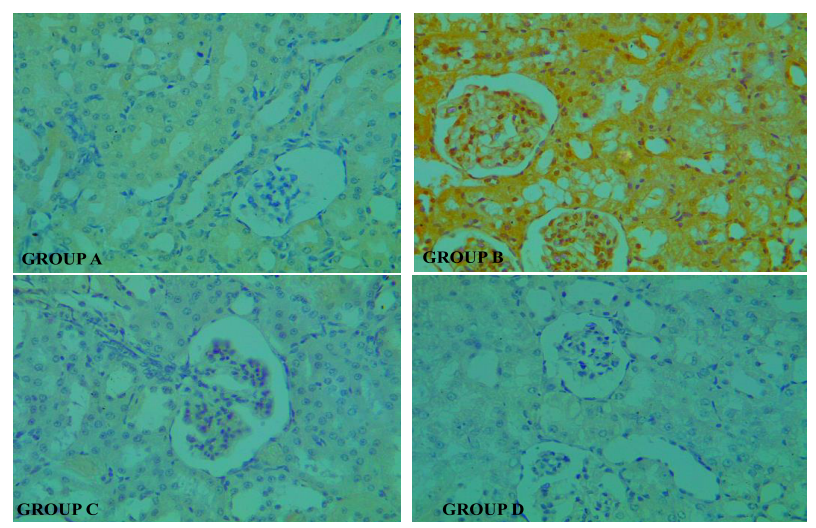

\begin{tabular}{|l|l|}
\hline GROUP & $\begin{array}{l}\text { RENIN } \\
\text { RECEPTOR }\end{array}$ \\
\hline Control & $0.063 \pm 0.018$ \\
\hline Glycerol alone & $88.0 \pm 7.8^{\mathrm{a}}$ \\
\hline $\begin{array}{l}\text { Glycerol } \\
\text { Pioglitazone }\end{array}$ & $0.06 \pm 0.02^{\mathrm{b}}$ \\
\hline $\begin{array}{l}\text { Glycerol } \\
\text { Ramipril }\end{array}$ & $0.02 \pm 0.003^{\mathrm{b}}$ \\
\hline
\end{tabular}

- CONTROL

- GLYCEROL ALONE

- GLYCEROL+PIOGLITAZONE — GLYCEROL+RAMIPRIL
Figure 6: The toxicant group (glycerol alone) caused significant expression of renin receptor while ramipril and pioglitazone caused significant inhibition of expression of this protein. The effect of these drugs on the protein expression is similar to that of the control.

\section{IMMUNOHISTOCHEMISTRY OF KIM-1}
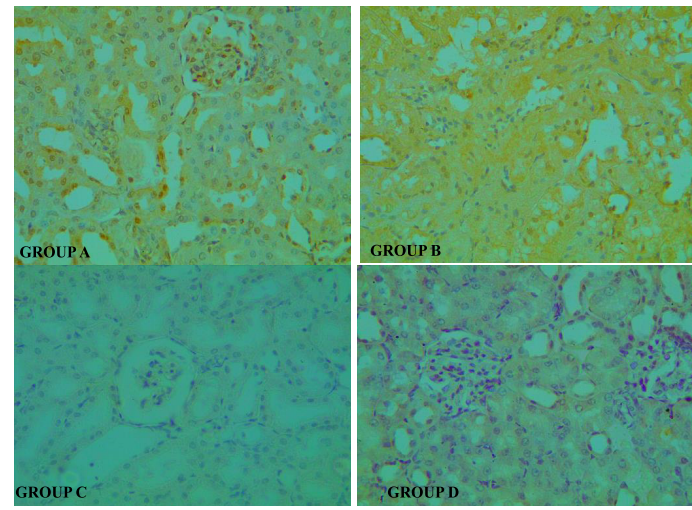

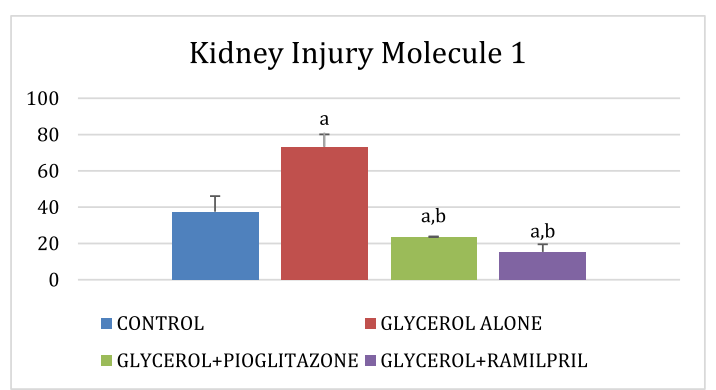

\begin{tabular}{|l|l|}
\hline GROUP & Kim-1 \\
\hline Control & $37.5 \pm 8.6$ \\
\hline Glycerol alone & $73.3 \pm 6.8^{\mathrm{a}}$ \\
\hline $\begin{array}{l}\text { Glycerol }+ \\
\text { Pioglitazone }\end{array}$ & $23.7 \pm 0.2^{\mathrm{ab}}$ \\
\hline $\begin{array}{l}\text { Glycerol + } \\
\text { Ramipril }\end{array}$ & $15.3 \pm 4.2^{\mathrm{ab}}$ \\
\hline
\end{tabular}

Figure 7: The toxicant group (glycerol alone) caused significant expression of kidney injury molecule-1 (KIM-1) while ramipril and pioglitazone caused significant inhibition of expression of this protein. The effect of these drugs on the protein expression is more pronounced even that of the control. 


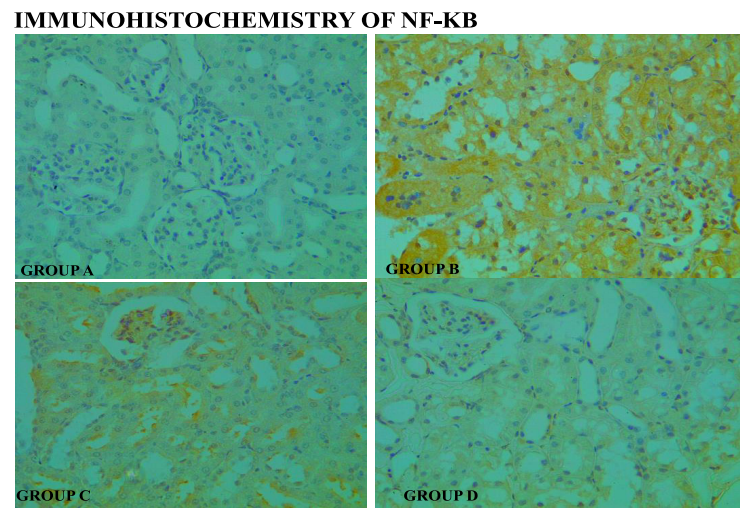

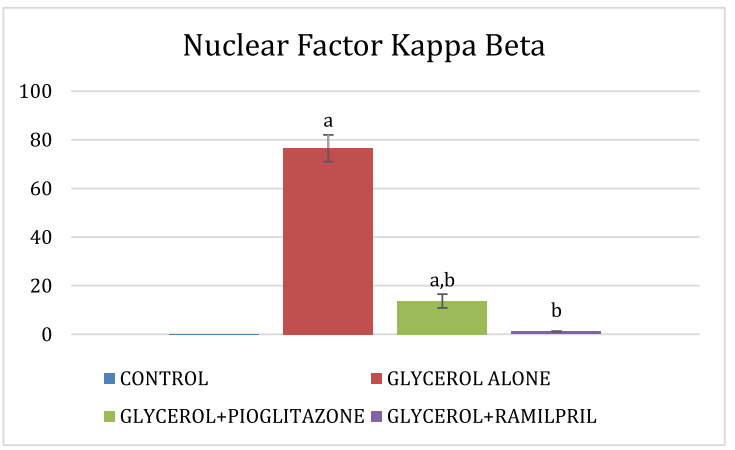

\begin{tabular}{|l|l|}
\hline GROUP & NF-KB \\
\hline Control & $0.03 \pm 0.0002$ \\
\hline $\begin{array}{l}\text { Glycerol } \\
\text { alone }\end{array}$ & $76.5 \pm 5.5^{\mathrm{a}}$ \\
\hline $\begin{array}{l}\text { Glycerol }+ \\
\text { Pioglitazone }\end{array}$ & $13.7 \pm 2.8^{\mathrm{ab}}$ \\
\hline $\begin{array}{l}\text { Glycerol }+ \\
\text { Ramipril }\end{array}$ & $1.2 \pm 0.06^{\mathrm{b}}$ \\
\hline
\end{tabular}

Figure 8: The toxicant group (glycerol alone) caused significant expression of nuclear factor kappa B (NF-KB) while ramipril and pioglitazone caused significant inhibition of expression of this protein. The effect of these drugs on the protein expression is similar to that of the control. intracellular agent, a potent reducing agent, which protects the tissue against destruction by free radicals. The thiol depletion in renal tissues in this study thus proves that glycerol exerts its damaging effect by depleting thiol levels, thus exacerbating oxidative damage.

There was a significant lowering of the vitamin C levels in the glycerol alone group, while the treated groups however had their vitamin $\mathrm{C}$ levels elevated to that of the control group due to the ramipril and pioglitazone treatment. Vitamin C is an important nonenzymatic antioxidant, which protects the aqueous compartments in cells [54]. It acts primarily by scavenging free radicals. In a previous study, depletion in vitamin $C$ levels in renal disease was reported [55]. It could thus be seen that the ability of ramipril, an ACE inhibitor, to enhance both enzymatic and nonenzymatic antioxidant as shown in this work is an attestation to its antioxidant property. Antioxidants prevent oxidation [56], which is a chemical reaction that can generate free radicals and subsequent chain reactions that may injure the cell [57].SOD catalyzes the breakdown of the superoxide anion into oxygen and hydrogen peroxide [58] while GSH's antioxidant property is due to its thiol group, which can serve as reducing agent, thus acting to protect the body from oxidation [59]. Because superoxide is a common ROS from many processes, its dismutation by SOD is very essential in each cell [60]. SOD acts by converting superoxide to the less deleterious hydrogen peroxide. The detoxification mechanism of ROS is done by GPx, GST. GPx has been said to act by inhibiting lipid peroxidases, thus supporting the concurrent decrease in GPx plus increase in MDA levels seen in this study. The significant increase in the level of the enzymatic antioxidants as seen in this study further showed that ramipril and by extension pioglitazone inhibit ARF due to these facts. Therefore part of its renoprotective effect is due to enhancement of enzymatic antioxidant, thus showing its antioxidant effect.

Glycerol is reported to cause a decline in levels of SOD and GPx [12]. In this study, SOD, GST, and GPx levels were significantly lowered in the toxicant group. Ramipril and pioglitazone, however, elevated their levels significantly as seen in Table 2. This investigation showed that the GST and GPx values in the toxicant groups were significantly depleted indicating that glycerol administration brought about oxidative stress. However, the elevation of SOD, GST, and GPx levels in the ramipril and pioglitazonetreated groups to almost the same as the control group is an indication that these drugs have the ability to enhance these enzymes, thus possessing antioxidant property. In this study, glycerol caused nephrotoxic changes such as zones of congestion, infiltration of inflammatory cells, 
and degeneration of renal cells in the kidney. The release of muscle content into the plasma in rhabdomyolysis leads to AKI through different mechanisms, such as tubular damage associated with pro-oxidants production [42]. Inflammatory cells infiltration, which was observed in this study, has also been stated in other studies, and this has been said to be an important mechanism of kidney damage [16]. Pioglitazone, an antidiabetic classified as PPARy agonist has been reported to have nephroprotective property, though its mechanism of action is not yet fully known [6].

In this study, four biomarkers were explored using immunohistochemistry to determine the nephroprotective effects of ramipril in glycerol-induced AKI. These biomarkers are: renin receptor, caspase 3, KIM-1, and NF-kB. Renin receptor has been reported to contribute to the pathogenesis of disease conditions such as fibrosis, AKI, cardiovascular disease, diabetic microangiopathy, preeclampsia, cancer hypertension, and obesity [61]. In this study, ramipril along with pioglitazone caused a significant inhibition of renin receptor. Renin receptor contributes to AKI especially that evidence suggests that inflammation is a crucial element contributing to the progression of AKI. It means that indicators of inflammation are of interest in the evaluation of AKI pathogenesis and prognosis [62]. The ability of ramipril to inhibit renin receptor therefore will halt the progression of AKI.

Caspases are important for maintaining homeostasis by controlling inflammation and cell death, but dysfunctional caspases trigger several human diseases including cancer and inflammatory disorders [63]. The role of caspase 3 in mediating the destruction of cellular structures gives it the name "executioner caspase" in apoptosis, hence is therefore a useful tool in mechanistic investigations of new cancer drugs [64]. In this study, ramipril caused significant inhibition of caspase 3; thus the drug acted through their antiapoptotic anti-inflammatory properties to blunt AKI in rats. The effect of ramipril on caspase is similar to that of pioglitazone, the reference drug used in this study.

KIM-1 is an indicator for quick discovery of AKI, because its level is considerably elevated within hours following kidney injury [65], but low expression is seen in normal kidneys but high in proximal tubule cells following AKI [66]. In this study, ramipril caused significant inhibition of KIM-1 indicating the ability of this drug to bring about nephroprotection, hence preventing kidney injury is one of the basis for its ability to mitigate against AKI. In fact, the effect of ramipril on KIM-1 is a bit more pronounced than that of pioglitazone in this study. Since timely diagnosis of AKI is still a challenge, the need to search for new biomarkers other than serum and creatinine becomes imperative. Khreba et al. [67] in their studies concluded that urinary KIM-1 could be used as simple noninvasive and specific biomarker for prompt diagnosis of AKI. In this study, the authors also agree with this postulation; thus efforts should be made at deploying KIM-1 and other biomarkers to make early detection of this diseased condition i.e., AKI.

The other protein evaluated in this study is NF-kB that influences not only immunity, but also inflammation, cancer, etc. [68-70]. NF-kB regulates gene expression - both negatively and positively [71], and it has also been shown that NF- $\mathrm{kB}$ signaling mediates several inflammatory processes [72-74]. In other words, NF-kB signaling is involved in inflammation; thus its significant inhibition in this study by ramipril is a pointer to the ability of the drug to mitigate inflammation and possible negative gene expression that this protein expressed. Ramipril also appears to exert more effect on NF-KB signaling pathway than pioglitazone, the reference drug.

\section{Conclusions}

Taken together, this study thus showed that ramipril in comparison to pioglitazone, the reference drug used in the study, both have nephroprotective effect and thus have the ability to blunt AKI through their anti-inflammatory, antiapoptosis, antirenin, and antioxidant properties.

Research funding: None declared.

Author contributions: All authors have accepted responsibility for the entire content of this manuscript and approved its submission.

Competing interests: Authors state no conflict of interest. Ethical approval: All experimental procedures were in conformity with the University of Ibadan Ethics Committee on Research in Animals with the institutional approval number as UI-ACUREC/17/0064.

\section{References}

1. Schrier RW, Wang W, Poole B, Mitra A. Acute renal failure: definitions, diagnosis, pathogenesis, and therapy. J Clin Invest 2004;114:5-14.

2. Lima RS, da Silva Jr. GB, Liborio AB, Daher ED. Acute kidney injury due to rhabdomyolysis. Saudi J Kidney Dis Transplant 2008;19: 721-9.

3. Boutaud O, Roberts LJ. Mechanism-based therapeutic approaches to rhabdomyolysis-induced renal failure. Free Radic Biol Med 2011; 51:1062-7. 
4. Chen CY, Lin YR, Zhao LL, Yang WC, Chang YJ, Wu HP. Clinical factors in predicting acute renal failure caused by rhabdomyolysis in the ED. Am J Emerg Med 2013;31:1062-6.

5. Chatzizisis YS, Misirli G, Hatzitolios Al, Giannoglu GD. The syndrome of rhabdomyolysis: complications and treatment. Eur J Intern Med 2008;19:568-74.

6. Mousleh R, Al Laham S, Al-Manadili A. The preventive role of pioglitazone in glycerol-induced acute kidney injury in rats during two different treatment periods. Iran J Med Sci 2018;43: 184-94.

7. Zager RA, Burkhart K. Myoglobin toxicity in proximal human kidney cells: roles of $\mathrm{Fe}, \mathrm{Ca}^{2+}, \mathrm{H}_{2} \mathrm{O}_{2}$, and terminal mitochondrial electron transport. Kidney Int 1997;51:728-38.

8. Gburek J, Birn H, Verroust PJ, Goj B, Jacobsen C, Moestrup SK, et al. Renal uptake of myoglobin is mediated by the endocytic receptors megalin and cubilin. Am J Physiol Ren Physiol 2003; 285:F451-8.

9. Reeder BJ, Wilson MT. Hemoglobin and myoglobin associated oxidative stress: from molecular mechanisms to disease states. Curr Med Chem 2005;12:2741-51.

10. Kim JH, Lee SS, Jung MH, Yeo HD, Kim HY, Yang J, et al. $\mathrm{N}$-acetylcysteine attenuates glycerol-induced acute kidney injury by regulating MAPKs and Bcl-2 family proteins. Nephrol Dial Transplant 2010;25:1435-43.

11. Wei Q, Hill WD, Su Y, Huang S, Dong Z. Heme oxygenase-1 induction contributes to renoprotection by G-CSF during rhabdomyolysis-associated acute kidney injury. Am J Physiol Ren Physiol 2011;301:F162-70.

12. Wu J, Pan X, Fu H, Zheng Y, Dai Y, Yin Y, et al. Effect of curcumin on glycerol-induced acute kidney injury in rats. Sci Rep 2017;31:10114.

13. Al Asmari AK, Al Sadoon KT, Obaid AA, Yesunayagam D, Tariq M. Protective effect of quinacrine against glycerol-induced acute kidney injury in rats. BMC Nephrol 2017;18:41.

14. Homsi E, de Brito SM, Janino P. Silymarin exacerbates p53-mediated tubular apoptosis in glycerol-induced acute kidney injury in rats. Ren Fail 2010;32:623-32.

15. Wang YD, Zhang L, Cai GY, et al. Fasudil ameliorates rhabdomyolysis-induced acute kidney injury via inhibition of apoptosis. Ren Fail 2011;33:811-8.

16. Korrapati MC, Shaner BE, Schnellmann RG. Recovery from glycerol-induced acute kidney injury is accelerated by suramin. J Pharmacol Exp Therapeut 2012;341:126-36.

17. Petejova N, Martinek A. Acute kidney injury due to rhabdomyolysis and renal replacement therapy: a critical review. Crit Care 2014;18:224.

18. Nishida K, Watanabe H, Ogaki S, Kodama A, Tanaka R, Imafuku T, et al. Renoprotective effect of long acting thioredoxin by modulating oxidative stress and macrophage migration inhibitory factor against rhabdomyolysis-associated acute kidney injury. Sci Rep 2015;5:14471.

19. Cebi G, Yildiz S, Uzun G, Oztas Y, Sabuncuoglu S, Kutlu A, et al. The effect of hyperbaric oxygen therapy on rhabdomyolysisinduced myoglobinuric acute renal failure in rats. Ren Fail 2016; 38:1554-9.

20. Sarafidis PA, Bakris GL. Protection of the kidney by thiazolidinediones: an assessment from bench to bedside. Kidney Int 2006;70:1223-33.
21. Radenkovic M. Pioglitazone and endothelial dysfunction: pleiotropic effects and possible therapeutic implications. Sci Pharm 2014;82:709-21.

22. Pereira MG, Camara NO, Campaholle G, Cenedeze MA, Teixeira VPA, Antonia des Reis M, et al. Pioglitazone limits cyclosporine nephrotoxicity in rats. Int Immunopharm 2006;6:1943-51.

23. Mahmoud MF, El Shazly SM. Pioglitazone protects against cisplatin- induced nephrotoxicity in rats and potentiates its anticancer activity against human renal adenocarcinoma cell lines. Food Chem Toxicol 2013;51:114-22.

24. Helmy MM, Helmy MW, El-Mas MM. Additive renoprotection by pioglitazone and fenofibrate against inflammatory, oxidative and apoptotic manifestations of cisplatin nephrotoxicity: modulation by PPARs. PLoS One 2015;10:e0142303.

25. Chen JW, Hsu NW, Wu TC, Lin SJ, Chang MS. Long-term angiotensin-converting enzyme inhibition reduces plasma asymmetric dimethylarginine and improves endothelial nitric oxide bioavailability and coronary microvascular function in patients with syndrome X. Am J Cardiol 2002;90:974-82.

26. Levitt DG, Schoemaker RC. Human physiologically based pharmacokinetic model for ACE inhibitors: ramipril and ramiprilat. BMC Clin Pharmacol 2006;6:1.

27. Santos RAS, Oudit GY, Verano-Braga T, Canta G, Steckelings UM, Bader M. The renin-angiotensin system: going beyond the classical paradigms. Am J Physiol Heart Circ Physiol 2019;316: H958-70.

28. Maraj I, Makaryus JN, Ashkar A, McFarlane M, Makaryus AN. Hypertension management in the high cardiovascular risk population. Int J Hypertens 2013:7:382802.

29. Ftouh S, Thomas M. Acute kidney injury guideline development group. Acute kidney injury: summary of NICE guidance. Br Med J 2013;347:f4930.

30. Case J, Khan S, Khalid R, Khan A. Epidemiology of acute kidney injury in the intensive care unit. Crit Care Res Pract 2013;2013:1e9.

31. Wolff SF. Ferrous ion oxidation in the presence of ferric ion indicator xylenol orange for measurement of hydrogen peroxides. Meth Enzymol 1994;233:182-9.

32. Varshney R, Kale RK. Effect of calmodulin antagonists on radiation induced lipid peroxidation in microsomes. Int J Radiat Biol 1990;58:733-43.

33. Reznick AZ, Packer L. Oxidative damage to proteins: spectrophotometric method for carbonyl assay. Methods Enzymol 1994;233:357-63.

34. Kayali R, Cakatay U, Akcay T, Altug T. Effect of alpha-lipoic acid supplementation on markers of protein oxidation in post-mitotic tissues of ageing rat. Cell Biochem Funct 2006;4:79-85.

35. Oyagbemi AA, Omobowale TO, Akinrinde AS, Saba AB, Ogunpolu $B S$, Daramola O. Lack of reversal of oxidative damage in renal tissues of lead acetate-treated rats. Environ Toxicol 2015;30: 1235-43.

36. Omóbòwálé TO, Oyagbemi AA, Ogunpolu BS, Ola-Davies OE, Olukunle JO, Asenuga ER, et al. Antihypertensive effect of polyphenol-rich fraction of Azadirachta indica on N $\omega$-Nitro-LArginine Methyl Ester-Induced hypertension and cardiorenal dysfunction. Drug Res 2018;69:11-22.

37. Olaleye SB, Adaramoye OA, Erigbali PP, Adeniyi OS. Lead exposure increases oxidative stress in the gastric mucosa of 
$\mathrm{HCl}$ /ethanol-exposed rats. World J Gastroenterol 2007;13: 5121-6.

38. Xia Y, Zweier JL. Measurement of myeloperoxidase in leukocytecontaining tissues. Anal Biochem 1997;245:93-6.

39. Drury RA, Wallington EA, Cancerson R. Carlton's Histopathological Techniques, 4th ed. Oxford, London, New York: Oxford University Press; 1996.

40. Oyagbemi AA, Omobowale TO, Asenuga ER, Adejumobi AO, Ajibade TO, Ige TM, et al. Sodium fluoride induces hypertension and cardiac complications through generation of reactive oxygen species and activation of nuclear factor kappa beta. Environ Toxicol 2017;32:1089-101.

41. Ai laham SA. The curative effects of methylsulfonylmethane against glycerol-induced acute renal failure in rats. Braz J Pharm Sci 2018;54:1-6.

42. Panizo N, Rubio-Navarro A, Amaro-Villalobos JM, Egido J, Moreno AM. Molecular mechanisms and novel therapeutic approaches to rhabdomyolysis-induced acute kidney injury. Kidney Blood Press Res 2015;40:520-32.

43. Palipoch S, Koomhin P. Oxidative stress-associated pathology: a review. Sains Malays 2015;44:1441-51.

44. Dalle-Donne I, Rossi R, Giustarini D, Milzani A, Colombo R. Protein carbonyl groups as biomarkers of oxidative stress. Clin Chim Acta 2003;329:23-38.

45. Ogunwa TH, Adeyelu T, Fasimoye RY, Oyewale MB, Ademoye TA, Ilesanmi $O C$, et al. Phytochemical evaluation and in vitro antioxidant status of Clerodendrum volubile (an indigenous medicinal plant). Pak J Pharm Sci 2010;2:77-88.

46. Oyagbemi AA, Omobowale TO, Ola-Davies OE, Asenuga ER, Ajibade TO, Adejumobi OA, et al. Luteolin-mediated Kim-1/NF-KB/ Nrf2 signaling pathways protects sodium fluoride-induced hypertension and cardiovascular complications. Biofactors 2018; 44:1-14.

47. Hsu CY, McCulloch CE, Fan D, Ordonez JD, Chertow GM, Go AS. Community-based incidence of acute renal failure. Kidney Int 2007;72:208-12.

48. Higgins C. Urea and the clinical value of measuring blood urea concentration. Available from: www.acutecaretesting.org [Accessed August 2016].

49. Aratani Y. Myeloperoxidase: its role for host defense, inflammation, and neutrophil function. Arch Biochem Biophys 2018;15:47-52.

50. Davies MJ. Myeloperoxidase-derived oxidation: mechanisms of biological damage and its prevention. J Clin Biochem Nutr 2011; 48:8-19.

51. Korhonen R, Lahti A, Kankaanranta H, Moilanen E. Nitric oxide production and signaling in inflammation. Curr Drug Targets Inflamm Allergy 2005;2:471-9.

52. Deneke SM. Thiol-based antioxidants. Curr Top Cell Regul 2000; 36:151-80.

53. Rossi R, Giustarini D, Milzani A, Dalle-Donne I. Cysteinylation and homocysteinylation of plasma protein thiols during ageing of healthy humans. J Cell Mol Med 2008;10:1582-4934.

54. Bhattacharya S. Reactive oxygen species and cellular defense system. In: Rani V, Yadav U, editors. Free radicals in human health and disease. Springer; 2015. https://doi.org/10.1007/ 978-81-322-2035-0.
55. Rahman T, Hosen I, Islam MMT, Shekhar HU. Oxidative stress and human health. Adv Biosci Biotechnol 2012;03:997-1019.

56. Dabelstein W, Reglitzky A, Schütze A, Readers K. Automotive fuels. Detroit, Michigan: Ullmann's Encyclopedia of Industrial Chemistry, Wiley; 2011.

57. Abner LE, Schmitt AF, Mendiondo SM, Marcum JL, Krysico RJ. Vitamin E and all-cause mortality: a meta-analysis. Curr Aging Sci 2011;4:158-70.

58. Zelko IN, Mariani TJ, Folz RJ. Superoxide dismutase multigene family: a comparison of the CuZn-SOD (SOD1), Mn-SOD (SOD2), and EC-SOD (SOD3) gene structures, evolution, and expression. Free Rad Biol Med 2002;33:337-49.

59. Meister A. Glutathione-ascorbic acid antioxidant system in animals. J Biol Chem 1994;269:9397-400.

60. Birben E, Murat U, Md S, Erzurum S, Kalayci O. Oxidative stress and antioxidant defense. WAO J 2012;5:9-19.

61. Ichihara A, Yatabe MS. The (pro)renin receptor in health and disease. Nat Rev Nephrol 2019;15:693-712.

62. Aqeel SHB, Sanchez A, Batlle D. Angiotensinogen as a biomarker of acute kidney injury. Clin Kidney J 2017;10:759-68.

63. Mcllwain DR, Berger T, Mak TW. Caspase functions in cell death and disease. Cold Spring Harb Perspect Biol 2019;5:30.

64. Parrish AB, Freel CD, Kornbluth S. Cellular mechanisms controlling caspase activation and function. Cold Spring Harb Perspect Biol 2013;24:1-24.

65. Han WK, Bailly V, Abichandani R, Thadhani R, Bonventre JV. Kidney Injury Molecule-1 (KIM-1): a novel biomarker for human renal proximal tubule injury. Kidney Int 2002;62:237-44.

66. Charlton JR, Portilla D, Okusa MD. A basic science view of acute kidney injury biomarkers. Nephrol Dial Transplant 2014;29: 1301-11.

67. Khreba NA, Abdelsalam M, Ahab AM, Sanad M, Elhelaly R, Adel M, et al. Kidney injury molecule 1 (KIM-1) as an early predictor for acute kidney injury in post-cardiopulmonary bypass (CPB) in open-heart surgery patients. Hindawi Int J Nephrol 2019;2019:6. 6265307.

68. Albensi BC, Mattson MP. Evidence for the involvement of TNF and NF-kappa B in hippocampal synaptic plasticity. Synapse 2000; 35:151-9.

69. Kaltschmidt B, Kaltschmidt C. NF-kappa B in the nervous system. Cold Spring Harb Perspect Biol 2009;1:a001271.

70. Karin M. NF-kappa B as a critical link between inflammation and cancer. Cold Spring Harb Perspect Biol 2009;1:a000141.

71. Mattson MP, Culmsee C, Yu Z. Roles of nuclear factor kappa B in neuronal survival and plasticity. J Neurochem 2000;74: 443-56.

72. Lamas O, Moreno-Aliaga MJ, Martinez JA, Marti A. NF-kappa B-binding activity in an animal diet-induced overweightness model and the impact of subsequent energy restriction. Biochem Biophys Res Commun 2003;311:533-9.

73. Mauro C, Leow SC, Anso E, Rocha S, Thotakura AK, Tornatore L, et al. NF-kappa B controls energy homeostasis and metabolic adaptation by upregulating mitochondrial respiration. Nat Cell Biol 2011;13:1272-9.

74. Moretti M, Bennett J, Tornatore L, Thotakura AK, Franzoso G. Cancer: NF-kappa B regulates energy metabolism. Int J Biochem Cell Biol 2012;44:2238-43. 